\title{
75 Years of Leading Global Archaeology: A Celebration of the Institute of Archaeology
}

\author{
Andrew Reynolds*
}

2012 saw an unparalleled coming together of Institute of Archaeology staff and students, past and present, in a celebration of its sustained achievements over the past 75 years. As a widely respected and universally appreciated hub for archaeology on the global scale, the Institute has trained generations of world-leading scholars and industry professionals, and many others who have taken the skills and experience acquired at the Institute into a variety of other disciplines, including the worlds of politics and international diplomacy, media, economics and music, to name but a few.

The sense of belonging to a community extends beyond the duration of a degree course as attendance at the raft of events organised to celebrate the 75th Anniversary of the Institute showed. Over 2,500 people attended fourteen events, with ex-staff and students coming from overseas as well as the UK.

\section{The 75th Anniversary Lecture}

Each year the Institute of Archaeology hosts a leading figure to present a major public lecture. During this special year, we were most fortunate to attract Professor Daniel Lord Smail from Harvard University who delivered the Anniversary Lecture, on 19 January, about 'History and the Pre: Perspectives on the Structure of Deep Historical Arguments', in the UCL Darwin Lecture Theatre (Fig. 1), followed by a reception in the Wilkins North Cloisters. The lecture drew a wide audience and tackled a series of major themes in the study of human societies with resonances for all present. A review of Professor Smail's lecture can be found at: http://www.ucl.ac.uk/archaeology/about/75th_anniversary/75th_reviews/ smail-anniversary-lecture.

" UCL Institute of Archaeology,

London WC1H OPY, United Kingdom

a.reynolds@ucl.ac.uk

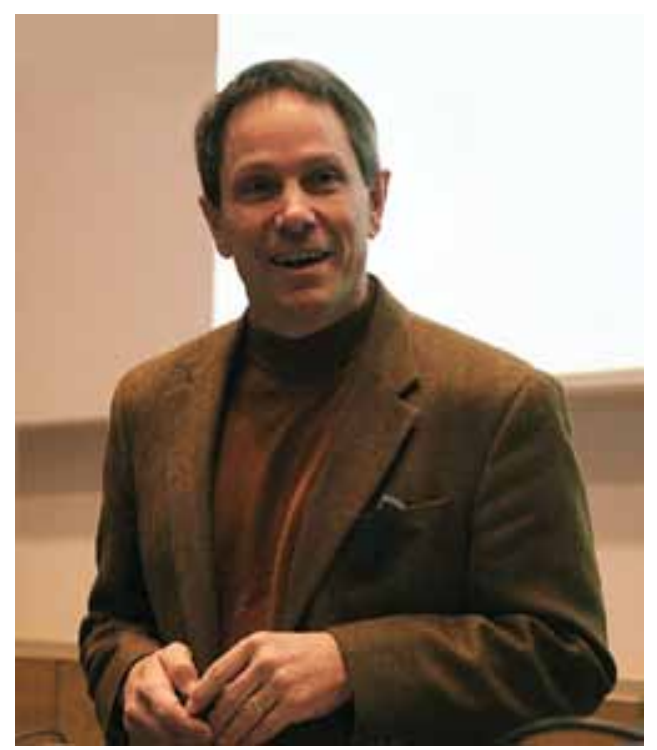

Fig. 1: Professor Daniel Lord Smail of Harvard University delivering the 75th Anniversary Lecture. Photo: Lisa Daniel. 


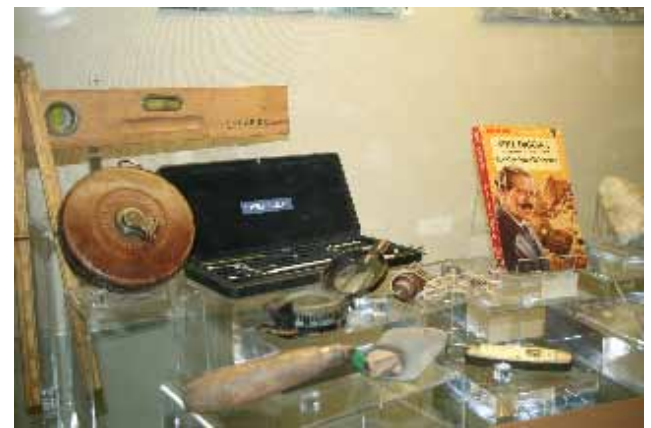

Fig. 2: Part of the Breaking Ground exhibition in the A.G. Leventis Gallery. Photo: Andrew Reynolds.

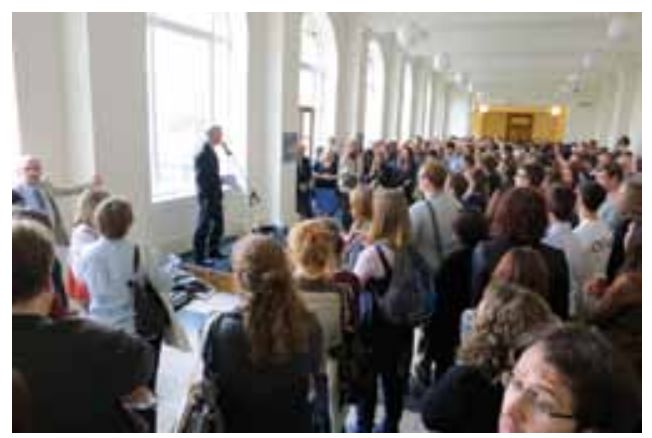

Fig. 3: Staff and students, past and present, gather in UCL to celebrate 75 years of the Institute of Archaeology. Photo: Lisa Daniel.

\section{Anniversary Inaugural Lectures}

The celebrations unfolded with the series of six inaugural lectures by recently promoted professors, as described above (p. 7), on themes which have been central to the development of the Institute of Archaeology or in which the Institute has taken a worldleading role.

Each lecture, introduced by Stephen Smith, Dean of the Faculty of Social \& Historical Sciences, was full to capacity and followed by a lively reception in the Institute's A. G. Leventis Gallery. The first was by Cyprian Broodbank who explored 'The Making of the Middle Sea: How the Mediterranean came into being', followed a week later by Elizabeth Pye who spoke on 'Objects as Narrative'. The third lecture was given by Stephen Quirke, on 'Objects of Egypt: Outside the Time Frame', and Arlene Rosen spoke a week later on 'The Social Impact of Climate Change: An Archaeologist's Perspective'. The fifth lecture, "Nasty, Brutish and Short"? Re-making the Early Middle Ages', was given by Andrew Reynolds, with Sue Hamilton bringing the series to a close, on 'Landscapes with People: From Prehistoric Britain to Rapa Nui (Easter Island)'. Abstracts and reviews of all six lectures can be found at: http://www.ucl.ac.uk/ archaeology/calendar/75th-news/75th_inaugural_series.

\section{5th Anniversary Debates}

A series of five weekly 'Question Time' style debates, generously sponsored by CgMs Consulting, were held in February and March, with key public and professional figures considering a series of major themes relating to the role of archaeology in the modern world. These well-attended events, described below by Joe Flatman (pp. 35-39), took place in the Archaeology Lecture Theatre, followed by a reception in the A. G. Leventis Gallery, and were streamed live online. Reviews can be found at: http://www.ucl.ac.uk/archaeology/calendar/75thnews/75th_anniversary_ debates.

\section{5th Anniversary Exhibitions}

An exhibition was developed by Museum Studies MA students on the history of the Institute of Archaeology and its agendasetting research and teaching activities, making full use of the Institute of Archaeology Collections. On 10 May, Breaking Ground: 75 Years of Pioneering Archaeology opened to the public in the A. G. Leventis Gallery (Fig. 2), with a reception and the launch of an accompanying brochure. The making of this exhibition is described below by Adam Koszary (pp. 62-64), and further details can be found at: http:// www.ucl.ac.uk/archaeology/calendar/articles/20120510. 


\section{A weekend of celebrations}

The Institute's 75th Anniversary celebrations also included two further days of activities, on 8/9 June. Student (and staff) parties at the Institute have long been celebrated for their liveliness and sociability and the evening of Friday 8 June proved no exception (Fig. 3), with the largest ever turn out for such an event with over 500 people in attendance. The event was organised to bring together current Institute of Archaeology students and alumni - and coincided with the announcement of results for undergraduate finalists, combined with the Society of Archaeological Students' Summer Party. Speeches by current Director Stephen Shennan and former Director David Harris reflected on past achievements while looking forward to exciting new ventures. Professor Shennan's speech can be found at: http://www.ucl.ac.uk/archaeology/about/75th_anniversary/75th_reviews/ shennan_anniversary_speech.

Saturday 9 June saw the World Archaeology Festival: The Past on your Doorstep take place in the Gordon Square garden, immediately in front of the Institute of Archaeology. This major outreach event brought together staff of archaeological and related organisations with an association with the Institute - and engaged with the broader public as it coincided with the Bloomsbury Squares festival (Fig. 4). A mini 'Prim-Tech' proved to be a great public attraction with activities for all age groups and abilities. Deer butchery and ceramic manufacture were particularly popular, with many other experimental demonstrations and interactive activities on offer. Images of the day are available at: http://www.flickr.com/photos/uclnews/ sets/72157630132608246/.

\section{A royal visit: a long tradition}

The Princess Royal - Chancellor of the University of London - visited the Institute as part of the 75th Anniversary celebrations on 28 April (Fig. 5), when she inspected the archaeological conservation laboratories and viewed a series of project-focused exhibi-

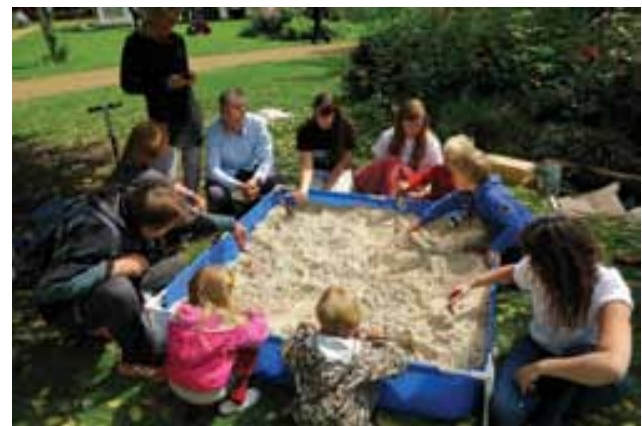

Fig. 4: A day of public outreach and engagement in Gordon Square. Photo: Charlotte Frearson.

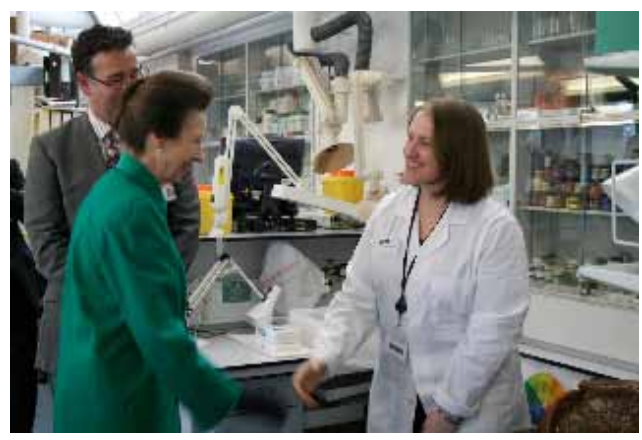

Fig. 5: The Princess Royal, as Chancellor of the University of London, visiting the UCL Institute of Archaeology in April 2012. Photo: Lisa Daniel.

tions and objects from the Institute's collections. The visit culminated in the unveiling of a plaque - now installed in the foyer - and a celebratory speech. This latest addition to the royal plaques in the foyer follows that marking the visit of the Queen Mother, as the then Chancellor, on the occasion of the opening of the present Institute building in 1958, and that of the current Chancellor's previous visit, marking the Institute's 50th Anniversary in 1987.

\section{Looking forward}

The good news is that from this year the 'summer party' will become an annual event where students and staff, past and present, can come together to meet old friends and 
make new contacts. The next such party will be held on 7 February 2013, in the South Cloisters at UCL: see the Institute's web pages for further developments.

To secure our future of leading global archaeology, a major fundraising drive is being launched towards the end of the anniversary year. This venture is intended as a two-way engagement between our ex-students and staff, and it is hoped that more of our alumni than ever before will re-establish or develop their contacts with the Institute. To join us in looking forward, see Archaeology International online for recent news of Institute people and projects (http:// http://www. ai-journal.com/) and the Institute's web pages for information about current events (http://www.ucl.ac.uk/archaeology/). If you are not already a member, keep up with the most recent developments by joining our growing online Facebook and Twitter communities at:

- https://www.facebook.com/pages/UCLArchaeology/384224188258510?sk=wa ll, and

- https://twitter.com/IoA_UCL_Friends.

A Flickr gallery of images relating to the 75th Anniversary can be found at:

- http://www.flickr.com/photos/ uclnews/sets/72157629357377493/ show/ 